\title{
Prevention and control of bovine cysticercosis: a Delphi study
}

\section{Medidas de prevenção e controle da cisticercose bovina: um estudo Delphi}

\author{
Elizandro Pruence Nickele ${ }^{1 *}$; Maria Assunta Busato ${ }^{2}$
}

\begin{abstract}
Bovine cysticercosis is a zoonotic parasitic infection caused by the larval stage (Cysticercus bovis) of Taenia saginata. This study aimed to identify prevention and control measures for bovine cysticercosis indicated by experts in the fields of public and animal health. The study was conducted through three rounds of the Delphi method and had the participation of 44 experts from 13 Brazilian states in 30 educational institutions, research institutions, and sanitary inspection services. The first round comprised an open question, the answers to which formed the basis for structuring the second and third questionnaire. To reach a consensus in the second and third rounds, experts were asked to express their agreement or disagreement of each proposition on the questionnaire using a five-point Likert scale. A descriptive statistical analysis was performed at the end of each round. Twenty-three specialists (52.27\%) participated in all three rounds. The first round resulted in 28 proposals categorized into six areas: health education, methods of diagnosis and treatment, sanitation measures, epidemiological studies, legislation and sanitary supervision, and intersectorality. In the second round, the experts reached a consensus on 16 propositions $(57.14 \%)$. This percentage increased by $3.54 \%$ during the third round. At the end of the third round, the experts had reached a consensus on 17 of the 28 initial propositions $(60.71 \%)$. The highest percentage of agreement (29.4\%) was observed in the category of health education. This study allowed us to identify 17 recommendations pertaining to the prevention and control of bovine cysticercosis. These measures are not mutually exclusive, and require an integrated approach to the establishment of intervention actions at various points in the life cycle of the parasite.
\end{abstract}

Key words: Environment. Parasitosis. Public health.

\section{Resumo}

A cisticercose bovina é uma infecção parasitária zoonótica causada pelo estágio larval (Cysticercus bovis) da Taenia saginata. Este estudo teve como objetivo identificar as medidas de prevenção e controle da cisticercose bovina indicadas por especialistas na área da saúde pública e animal. O estudo foi realizado através de três rodadas do método Delphi e contou com a participação de 44 especialistas de 13 estados brasileiros em trinta instituições de ensino, pesquisa e serviços de inspeção sanitária. A primeira rodada foi composta de uma questão aberta cujas respostas serviram de base para a estruturação do segundo e terceiro questionário. Para obtenção de consenso, na segunda e terceira rodada, os especialistas foram convidados a expressarem sua concordância ou discordância para cada proposição do questionário através de uma escala de Likert de cinco pontos. A análise estatística descritiva foi realizada no final de cada rodada. Vinte e três $(52,27 \%)$ especialistas participaram das três rodadas. A primeira rodada resultou em 28 propostas classificadas em seis áreas: educação em saúde, métodos de

\footnotetext{
${ }^{1}$ M.e em Ciências da Saúde, Universidade Comunitária da Região de Chapecó, UNOCHAPECÓ, Chapecó, SC, Brasil. E-mail: enickele@chapeco.sc.gov.br

${ }^{2}$ Prof , Programa de Pós-Graduação em Ciências da Saúde, UNOCHAPECÓ, Chapecó, SC, Brasil. E-mail: assunta@unochapeco. edu.br

* Author for correspondence
} 
diagnóstico e tratamento, medidas de saneamento, estudos epidemiológicos, legislação e fiscalização sanitária e intersetorialidade. Na segunda rodada, $16(57,14 \%)$ proposições obtiveram consenso entre os especialistas. Houve um aumento neste percentual de 3,54\% durante a terceira rodada. Ao término da terceira rodada, $17(60,71 \%)$ proposições, das 28 iniciais, obtiveram consenso entre os especialistas. O maior percentual de consenso foi verificado no eixo educação em saúde $(29,4 \%)$. Os resultados deste estudo permitiram identificar 17 recomendações para a prevenção e controle da cisticercose bovina. Estas medidas não são excludentes, e exigem uma abordagem integrada para o estabelecimento de ações de intervenção em vários pontos do ciclo de vida do parasito.

Palavras-chave: Ambiente. Parasitose. Saúde pública.

\section{Introduction}

Bovine cysticercosis is a zoonotic parasitic infection caused by the larval stage (Cysticercus bovis) of Taenia saginata. Infection of cattle is an important issue of food security, as well as an economic concern in many areas of the world (GEYSEN et al., 2007).

Cattle are infected by eating eggs (or proglottids) of $T$. saginata and, once infected, will develop cysticerci in the muscles. Infection in humans, the definitive host, results from the ingestion of raw or partially cooked meat containing viable cysticerci (MURRELL, 2005).

The risk of infection is higher wherever personal hygiene, breeding practices, waste management, and knowledge of the infection are inadequate (MURRELL, 2013). The high biotic potential of the parasite, the efficient dissemination of $T$. saginata's eggs into the environment, and the role of intermediate hosts are epidemiological characteristics that favor the stability of the taeniasis/ cysticercosis complex (GEERTS, 1990).

Bovine cysticercosis is not usually accompanied by clinical signs. Infection of the bovine intermediate host is characterized by the presence of cystic lesions of approximately 5-10 $\mathrm{mm}$ in length that are most commonly found in the heart muscle, tongue, diaphragm, and masseter, although all muscle tissues can be affected (JENKINS et al., 2013). In humans, taeniasis can cause abdominal pain, nausea, weakness, weight loss, bloating, diarrhea, or constipation (BRASIL, 2010). Occasionally, the migration of proglottids may result in appendicitis or cholangitis (JONGWUTIWES et al., 2004).

Because it is a public health problem, the Ministry of Health advises that prevention and control measures for parasitosis be used, particularly education, environmental control, and inspection of meat (BRASIL, 2010). During postmortem inspection of cattle carcasses and offal, the sanitary inspection service can generate data for epidemiological studies of parasitosis (ALMEIDA et al., 2006).

The establishment of control and prevention measures of parasitic zoonoses is a complex task that requires an integrated and multidisciplinary approach. The reduction of the parasite load is an important goal, but environmental and ecological changes need to be implemented to reduce the risk of transmission of the parasite (CHOMEL, 2008; MURRELL, 2005).

This study used the Delphi method, which is characterized by the collection of experts' opinions on a topic through several rounds of questionnaires, until a convergence of responses or a consensus is achieved. For Varela-Ruiz et al. (2012), using the Delphi method in scientific research allows for individuals with different perspectives to reach a consensus on topics of interest. The Delphi method has been previously used in the area of food safety, for setting priorities in animal and public health (BEHMANN et al., 2012; KIM et al., 2013; MORE et al., 2010).

The purpose of the present study was to obtain the opinions of a group of Brazilian experts on the 
prevention and control of bovine cysticercosis. The suggestions proposed by the experts, collected and systematized using the Delphi method, may contribute to the development of programs for the prevention and control of the biological cycle of this disease.

\section{Material and Methods}

Teachers with doctoral degrees who have done research within the area of this study were selected to participate. Teachers were sought from within faculty programs that are recognized by the Coordination for the Improvement of Higher Education Personnel [Coordenação de Aperfeiçoamento de Pessoal de Nível Superior (CAPES)]. Professionals from the Health Inspection Services operating at cattle slaughtering units registered with the Federal Inspection Service (SIF/MAPA), professionals at the Brazilian Animal Products Inspection Service (SISBI/POA), and professionals working in the area of surveillance and epidemiology at the Ministry of Health and State Health Department also participated in this study. The aim was to include a number of experts, as recommended by Varela-Ruiz et al. (2012).

Data collection was conducted by email and took place from August to November 2013, through three rounds of the Delphi method (LANDETA, 2006). A letter introducing the study was sent to each expert, explaining the research objectives, the work methodology, and anonymity criteria. The first questionnaire (Q1) consisted of an open question, asking those professionals to indicate measures that they would recommend in order to implement a bovine cysticercosis control program. With the first questionnaire, the participants were required to complete a professional profile and to provide informed consent.

The answers from the first round were the basis for the preparation of the questionnaire for the second round (Q2). This time, the experts were asked to express their agreement or disagreement on each questionnaire proposition (Q2) using a five-point Likert scale: strongly disagree, disagree, do not agree or disagree, agree, or strongly agree (KIM et al., 2013). The proposals that obtained the highest level of agreement or for which at least $80 \%$ of respondents selected "agree" or "strongly agree" were considered to have reached a consensus.

The questionnaire for the third round (Q3) was drawn from the proposals that did not reach a consensus in the second round. At this stage, each expert could compare their positions to the group's opinions, and had the option of maintaining or changing their position.

Data analysis was carried out interactively at the end of each round, in order to provide the group's feedback to each participant in statistical terms. Qualitative analysis of the responses from the first round was carried out by repeated readings followed by recording possible meanings and grouping the responses into categories according to the similarity of the statements (BARDIN, 2011). For the second and third rounds, a descriptive analysis was applied. The agreement percentages for each proposition and for the variables in the respondents' professional profiles were obtained by analyzing answer frequencies using the program IBM SPSS Statistical Package for Social Sciences, Version 19.0.

This study was approved by the Ethics Committee on Research Involving Human Beings of the Community University of the Chapecó Region (UNOCHAPECÓ), under the Protocol No. $045 / 2013$.

\section{Results}

Results are presented using a research flowchart indicating the sequence of events of the Delphi method (Figure 1). 
Figure 1. Flowchart of the adopted Delphi method for the study of measures to prevent and control bovine cysticercosis, Brazil, 2013.

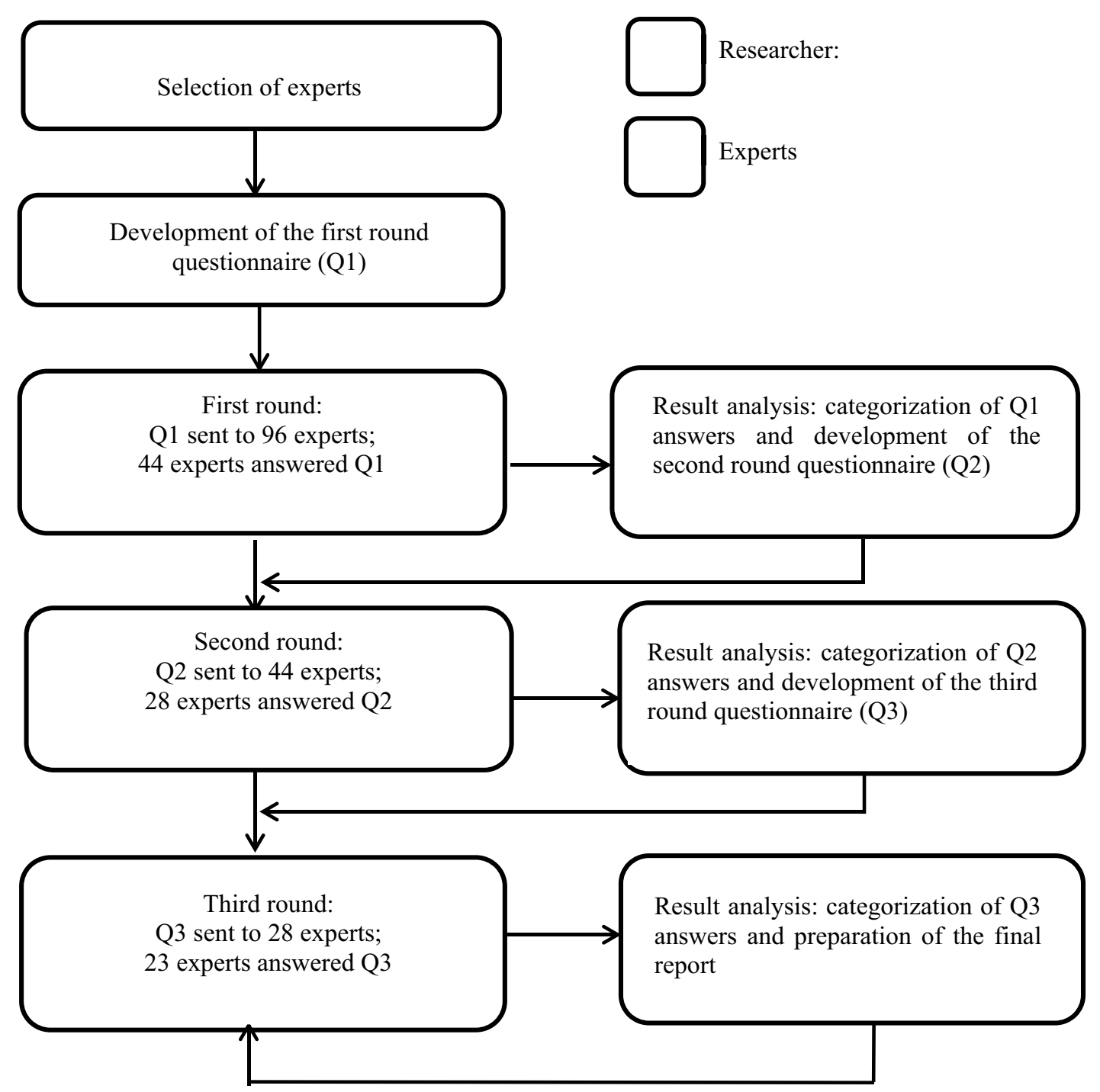

Initially, 96 experts were invited to participate in the survey (Q1) and 44 answered the questionnaire, which represents a rate of return of $44.83 \%$. They came from 13 Brazilian states and 30 educational and research institutions and veterinary inspection services. Of these, $68.18 \%$ were teachers of graduate programs and $31.82 \%$ worked in the fields of sanitary inspection and epidemiological surveillance. The highest percentage of respondents was experts in the areas of parasitology (31.82\%), followed by sanitary inspection (27.27\%).
The 138 proposals that were received were categorized into six areas: health education, methods of diagnosis and treatment, sanitation measures, epidemiological studies, legislation and sanitary supervision, and intersectoriality. These proposals, received in the first round (Q1), were systematized to avoid duplication, resulting in 28 proposals that became the basis for the preparation of the questionnaire for the second round (Q2).

In the second round, the questionnaire (Q2) was sent to the 44 experts that had participated in the 
first round and 28 responded, which corresponds to a return rate of $66.66 \%$.

These experts were asked to express their agreement or disagreement of each of the 28 propositions of the questionnaire $(\mathrm{Q} 2)$, according to a five-point Likert scale. In the second round, 16 proposals (57.14\%) achieved a consensus among experts. Twelve proposals $(42.85 \%)$ did not reach consensus and became the basis for the preparation of the questionnaire for the third round (Q3).

A report containing the 16 proposals that achieved consensus in the second round was attached to the third questionnaire for the experts' information. The third questionnaire (Q3) was sent to the 28 experts participating in the second round and was answered by 23 , which represents a return rate of $82.14 \%$. The 23 experts who participated in all stages of this study were from 17 educational and research institutions and veterinary inspection services from seven Brazilian states; 65.22\% were teachers and $34.78 \%$ worked in health surveillance and epidemiological surveillance. Of the 12 propositions reevaluated in the third round, only one reached a consensus among the experts, resulting in an increase of $3.57 \%$ relative to the consensus percentage of the second round.

At the end of the third round, 17 propositions (60.71\% of the 28 initial propositions) reached a consensus among the experts. The highest percentages of agreement were observed in the categories of health education (29.4\%) and actions related to intersectorality $(23.5 \%)$.

\section{Discussion}

Recommendations related to health education (Table 1) reached the greatest consensus
(29.4\%), including actions ranging from basic school training to guidance of beef consumers. The emphasis put on health education shows the importance of integrated actions involving different sectors, keeping in mind that it is necessary to know the local characteristics of each region as well as the economic, social, cultural, and environmental determinants of the population.

Health education can be considered the key factor influencing continued involvement in programs of prevention and control of cysticercosis (KYVSGAARD; MURRELL, 2005). Measures to encourage proper cooking of food, improve hygiene levels, and promote proper use of sanitary facilities may be challenging, due to the cultural and social significance of these practices (MACPHERSON, 2005). All those directly or indirectly involved in the prevention of taeniasis/ cysticercosis should participate in the health education process (SANCHEZ; FAIRFIELD, 2003).

In the thematic area of diagnostic and treatment methods, only one proposition (5.9\%) achieved consensus among the experts, including recommendations on the treatment of individuals and households involved in outbreaks of parasitosis. In this sense, the identification of animals with cysticercosis during slaughter can serve as an indication of parasitosis at the origin farms, as well as the presence of human carriers of taeniasis who act as sources of infection by releasing $T$. saginata in their feces (NIETO et al., 2012). Thus, health workers play a central role in identifying human carriers and in promoting better hygiene practices in the community (KYVSGAARD; MURRELL, 2005). 
Table 1. Frequency $(\%)$ of propositions $(n=17)$ that achieved consensus among experts in this study on prevention and control of bovine cysticercosis, Brazil, in 2013.

\begin{tabular}{lc}
\hline Categories & \% \\
\hline Health education: & 29.4
\end{tabular}

1-Educating the population on the consumption of well-cooked meats through educational campaigns.

2-Making duly inspected meat available in the market; warning about the risk of Taeniasis related to meat of illegal origin.

3-For middle and high school students, the topic should be mandatory when studying transverse health issues.

4-Sanitary education: information and communication strategies that discuss risk factors and differentiated vulnerabilities according to population profiles, using specific media according to the target public.

5-Interdisciplinary projects involving health education work, especially in schools.

\section{Intersectorality:}

1-Information on animal health protection agencies provided by health inspection services to farms with positive animals.

2-Need for integrated actions at a federal, state, and local level, involving the Ministries of Agriculture and Health, State and Municipal Agriculture, and Health Departments.

3-Cysticercosis found during health inspection must be communicated to Health Departments, mentioning the group of origin and the location of the farm, so that action, including health education programs, may be taken.

4-Integrated activity among professionals of the Family Health Program, educators, and social workers.

\section{Legislation and health surveillance:}

1-Inspection and supervision of the meat. This measure aims to reduce the marketing and consumption of cysticercosis-contaminated meat to the lowest possible levels.

2-Training of veterinary inspectors at a federal, state, and municipal level, focusing on the macroscopic diagnosis of the parasite.

3-Measures to combat illegal slaughterhouses.

\section{Sanitation measures:}

1-Basic sanitation in urban and rural areas. When this is not possible, use of septic tanks in rural homes to avoid environmental contamination.

2-Identification and elimination of contamination sources (particularly wastewater) of pastures and food provided to the animals.

\section{Epidemiological studies:}

1-Diagnosis of the regional situation relative to the occurrence of cases and their respective risk factors for human taeniasis and bovine cysticercosis.

2-Disclosure of nosographic data (inspection findings) in scientific journals in order to disseminate information on the prevalence of cysticercosis and epidemiological factors involved in cycle maintenance. This information will be used to map out effective control measures specific to each region.

\section{Methods of diagnosis and treatment:}

1-Treatment of individuals and households in areas where cases of bovine cysticercosis are reported.

There was no consensus among the panelists as to the histopathologic analysis of dead cysticerci for the identification of limestone corpuscles, but microscopic procedures have been used in the diagnosis of nodular caseous and/or calcified lesions (COSTA et al., 2012; TESSELE et al., 2013). The polymerase chain reaction (PCR) and its variation (real-time PCR) have been used for the molecular 
diagnosis of bovine cysticercosis lesions in the laboratory (COSTA et al., 2012; CUTTELL et al., 2013; GEYSEN et al., 2007).

Regarding the establishment of sanitation measures, the two propositions (11.8\%) reached consensus among the experts. Sanitation measures are recommended in both urban and rural areas. For rural areas, the construction of septic tanks was recommended in order to prevent possible environmental contamination and impede the parasite cycle, as deficiencies in sanitation contribute to the spread of eggs carrying the parasite into the environment. Epidemiological studies describe bovine cysticercosis outbreaks due to the dispersion of wastewater in pastures and food (CABARET et al., 2002; CALVO-ARTAVIA et al., 2013). Thus, it is necessary to promote an integrated approach that addresses basic sanitation, improved water supply, and health education (KYVSGAARD; MURRELL, 2005). Rossi et al. (2014) draw a connection between the taeniasis-bovine cysticercosis complex and inadequate production practices associated with sanitation deficiencies.

It is noteworthy that $11.8 \%$ of the propositions that obtained consensus in the study concerned performing epidemiological studies. Data on the prevalence of bovine cysticercosis from inspection services constitute an important indicator for government agencies and producers to establish measures for the control and prevention of the infection (NIETO et al., 2012). However, knowledge on the prevalence of bovine cysticercosis is inadequate due to low reporting and failure to systematize data for comparison (BAVIA et al., 2012).

Propositions related to surveillance and sanitation legislation consisted of $17.6 \%$ of the propositions that achieved consensus among the experts. Inspection and supervision of meat aim to reduce the sale and consumption of meat contaminated with cysticercosis. There is consensus among experts that these actions must be extended to the surveillance of illegal slaughterhouses. Routinely, the detection of bovine cysticercosis is based on pathological examination of random sites (ABUSEIR et al., 2013; SCANDRETT et al., 2009). The sensitivity of the routine inspection methodology may vary depending on the number and the stage of the cysts (McFADDEN et al., 2011). Often, cysticerci are found in locations outside those established in the inspection routine (MINOZZO et al., 2002). The difficulties involved in interpreting the results of visual inspection of meat emphasize the need to improve the current diagnostic tests, in order to strengthen the control of bovine cysticercosis (GEYSEN et al., 2007). For example, serological techniques have been employed for the diagnosis of bovine cysticercosis (ALLEPUZ et al., 2012, EICHENBERGER et al., 2013, GUIMARÃESPEIXOTO et al., 2015).

The control and prevention of parasitic zoonosis are complex tasks that require an integrated and multidisciplinary approach (CHOMEL, 2008). In the third round of the questionnaire, $23.5 \%$ of the propositions that obtained consensus among the experts pointed out the need to promote intersectoral action regarding the control of the parasite. As a way to improve incentive policies, integration actions should promote a long-term approach guided by cooperation among government, industry, and universities. This should result in the development of a program based on risk analysis, transparent public access to health data, and generation of consumer-oriented communications derived from that data (LYNCH; SILVA, 2013).

The importance of intersectoral actions to prevent and control this disease have been discussed in relation to the principle of comprehensiveness, in which, in a planned way, effective actions are taken to promote health and minimize risk (CAMPOS, 2003). 


\section{Conclusions}

This study identified 17 recommendations from relevant experts regarding the prevention and control of bovine cysticercosis. These measures are not mutually exclusive, and require an integrated approach towards the establishment of intervention actions at various points in the life cycle of the parasite.

The recommendations focused on the areas of parasitology education and sanitary inspection. Although the interdisciplinary composition of the panel may allow for a wider range of opinions on the subject, the heterogeneity of the professional profiles of the experts may also result in varying degrees of knowledge about the analyzed propositions.

The use of the Delphi method has been recommended in other studies on public and animal health. In this study, the method was used successfully to exchange views among respondents in different regions of the country and to obtain a consensus for the prioritization of parasitosis intervention actions.

\section{Acknowledgements}

The authors acknowledge the Support Fund for the Maintenance and Development of Higher Education (FUMDES) of the State Department of Education of the State of Santa Catarina, for granting a scholarship for the study.

\section{References}

ABUSEIR, S.; NAGEL-KOHL, U.; WOLKEN, S.; STRUBE, C. An immunoblot for detection of Taenia saginata cysticercosis. Parasitology Research, Berlin, v. 112, n. 5, p. 2069-2073, 2013.

ALLEPUZ, A.; GABRIËL, S.; DORNY, P.; NAPP, S.; JANSEN, F.; VILAR, M. J.; VIVES, L.; PICART, L.; ORTUNO, A.; GUTIÉRREZ, J.; CASAL, J. Comparison of bovine cysticercosis prevalence detected by antigen ELISA and visual inspection in the North East of Spain. Research in Veterinary Science, London, v. 92, n. 3, p. 393-395, 2012.
ALMEIDA, D. O.; IGREJA, H. P.; ALVES, F. M. X.; SANTOS, I. F.; TORTELLY, R. Cisticercose bovina em matadouro-frigorífico sob inspeção sanitária no município de Teixeira de Freitas-BA: prevalência da enfermidade e analise anatomopatológica de diagnóstico sugestivo de cisticercose. Revista Brasileira Ciência Veterinária, Niterói, v. 13, n. 3, p. 178-182, 2006.

BARDIN, L. Análise de conteúdo. São Paulo: Edições 70, 2011. 229 p.

BAVIA, M. E.; CARNEIRO, D. D. M. T.; CARDIM, L. L.; SILVA, M. M. N.; MARTINS, M. S. Estatística espacial de varredura na detecção de áreas de risco para a cisticercose bovina no Estado da Bahia. Arquivo Brasileiro de Medicina Veterinária e Zootecnia, Belo Horizonte, v. 4, n. 5, p. 1200-1208, 2012.

BEHMANN, M.; JÜNGER， S.; RADBRUCH， L.; SCHNEIDER, N. Public health actions to improve palliative care in Germany: results of a three-round Delphi study. Health Policy, Amsterdam, v. 106, n. 3, p. 303-312, 2012.

BRASIL. Ministério da Saúde. Doenças infecciosas e parasitárias: guia de bolso. 8. ed. Brasília: Ministério da Saúde, 2010. 448 p.

CABARET, J.; GEERTS, S.; MADELINE, M.; BALLANDONNE, C.; BARBIER, D. The use of urban sewage sludge on pastures: the cysticercosis threat. Veterinary Research, Paris, v. 33, n. 5, p. 575-597, 2002.

CALVO-ARTAVIA, F. F.; NIELSEN, L. R.; DAHL, J.; CLAUSEN, D. M.; GRAUMANN, A. M.; ALBAN, L. A case-control study of risk factors for bovine cysticercosis in Danish cattle herds. Zoonoses and Public Health, Berlin, v. 60, n. 4, p. 311-318, 2013.

CAMPOS, C. E. A. O desafio da integralidade segundo as perspectivas da vigilância da saúde e da saúde da família. Ciência e Saúde Coletiva, Rio de Janeiro, v. 8, n. 2, p. 509-584, 2003.

CHOMEL, B. B. Control and prevention of emerging parasitic zoonoses. International Journal for Parasitology, Oxford, v. 38, n. 11, p. 1211-1217, 2008.

COSTA, R. F. R.; SANTOS, I. F.; SANTANA, A. P.; TORTELLY, R.; NASCIMENTO, E. R.; FUKUDA, R. T.; CARVALHO, E. C. Q.; MENEZEZ, R. C. Caracterização das lesões por Cysticercus bovis, na inspeção post mortem de bovinos, pelos exames macroscópico, histopatológico e pela reação em cadeia da polimerase (PCR). Pesquisa Veterinária Brasileira, Rio de Janeiro, v. 32, n. 6, p. 477484, 2012.

CUTTELL, L.; OWEN, H.; LEW-TABOR, A. E.; TRAUB, R. J. Bovine cysticercosis-development of a 
real-time PCR to enhance classification of suspect cysts identified at meat inspection. Veterinary Parasitology, Amsterdam, v. 1, n. 194, p. 65-69, 2013.

EICHENBERGER，R. M.; LEWIS，F.; GABRIËL, S.; DORNY, P.; TORGERSON, P. R.; DEPLAZES, P. Multi-test analysis and model-based estimation of the prevalence of Taenia saginata cysticercus infection in naturally infected dairy cows in the absence of a 'gold standard' reference test. International Journal for Parasitology, Oxford, v. 43, n. 10, p. 853-859, 2013.

GEERTS, S. Taenia saginata: an eternal problem? Verhandelingen Koninklijke Academie voor Geneeskunde van België, Brussels, v. 52, n. 6, p. 537-563, 1990.

GEYSEN, D.; KANOBANA, K.; VICTOR, B.; RODRIGUEZ-HIDALGO, R.; DE BORCHGRAVE, J.; BRANDT, J.; DORNY, P. Validation of meat inspection results for Taenia saginata cysticercosis by PCR restriction fragment length polymorphism. Journal of food protection, Ames, v. 70, n. 1, p. 236-240, 2007.

GUIMARÃES-PEIXOTO, R. P. M.; PINTO, P. S. A.; NERO, L. A.; SANTOS, T. O.; SILVA, L. F.; ACEVEDO-NIETO, E. C.; RIVETTI JÚNIOR, A. V. Desempenho do ELISA no diagnóstico da cisticercose utilizando bovinos experimentalmente e naturalmente infectados com o metacestódeo de Taenia saginata. Semina: Ciências Agrárias, Londrina, v. 36, n. 2, p. 807-816, 2015.

JENKINS, D. J.; BROWN, G. K.; TRAUB, R. J. Cysticercosis storm in feedlot cattle in north-west New South Wales. Australian Veterinary Journal, Oxford, v. 91, n. 3, p. 89-93, 2013.

JONGWUTIWES, S.; PUTAPORNTIP, C.; CHANTACHUM, N.; SAMPATANUKUL, P. Jejunal perforation caused by morphologically abnormal Taenia saginata infection. Journal of Infection, London, v. 49, n. 4, p. 324-328, 2004.

KIM, K. K.; O'BRYAN, C. A.; CRANDALL, P. G.; RICKE, S. C.; NEAL, J. A. Identifying baseline food safety training practices for retail delis using the Delphi expert consensus method. Food Control, Kidlington, v. 32, n. 1, p. 55-62, 2013.

KYVSGAARD, N. C.; MURRELL, K. D. Prevention of taeniosis and cysticercosis. In: MURRELL, K. D. (Ed.). WHO/FAO/OIE guidelines for the surveillance, prevention and control of taeniosis/cysticercosis. Paris: World Health Organisation for Animal Health (OIE), 2005. p. 57-72.

LANDETA, J. Current validity of the Delphi method in social sciences. Technological Forecasting and Social Change, New York, v. 73, n. 5, p. 467-482, 2006.
LYNCH, J. A.; SILVA, P. Integrating animal health and food safety surveillance data from slaughterhouse control. Scientific and Technical Review of the Office International des Epizooties, Paris, v. 32, n. 2, p. 409416, 2013.

MACPHERSON, C. N. Human behaviour and the epidemiology of parasitic zoonoses. International Journal for Parasitology, Oxford, v. 35, n. 11-12, p. 1319-1331, 2005.

McFADDEN, A. M.; HEATH, D. D.; MORLEY, C. M.; DORNY, P. Investigation of an outbreak of Taenia saginata cysts (cysticercus bovis) in dairy cattle from two farms. Veterinary Parasitology, Amsterdam, v. 176, n. 2-3, p. 177-184, 2011.

MINOZZO, J. C.; GUSSO, R. L. F.; CASTRO, E. A.; LAGO, O.; THOMAZ-SOCCOL, V. Experimental bovine infection with Taenia saginata eggs: recovery rates and cysticerci location. Brazilian Archives of Biology and Technology, Curitiba, v. 45, n. 4, p. 451-455, 2002.

MORE, S. J.; McKENZIE, K.; O'FLAHERTY, J.; DOHERTY, M. L.; CROMIE, A. R.; MAGAN, M. J. Setting priorities for non-regulatory animal health in Ireland: results from an expert Policy Delphi study and a farmer priority identification survey. Preventive Veterinary Medicine, Amsterdam, v. 95, n. 3-4, p. 198207, 2010.

MURRELL, K. D. Epidemiology of taeniosis and cysticercosis. In: MURRELL, K. D. (Ed.). WHO/FAO/ OIE guidelines for the surveillance, prevention and control of taeniosis/cysticercosis. Paris: World Health Organisation for Animal Health (OIE), 2005. p. 27-43.

Zoonotic foodborne parasites and their surveillance. Scientific and Technical Review of the Office International des Epizooties, Paris, v. 32, n. 2, p. 559-569, 2013.

NIETO, E. C. A.; VIEIRA, F. C.; PINTO, P. S. A.; SILVA, L. F.; SANTOS, T. O.; PEIXOTO, R. P. M. G. Análise de fatores de risco para a infecção de cisticercose bovina: estudo de caso controle a partir de animais abatidos. Semina: Ciências Agrárias, Londrina, v. 33, n. 6, p. 2359-2366, 2012.

ROSSI, G. A. M.; GRISÓLIO, A. P. R.; PRATA, L. F.; BÜRGER, K. P.; HOPPE, E. G. L. Situação da cisticercose bovina no Brasil. Semina: Ciências Agrárias, Londrina, v. 35, n. 2, p. 927-938, 2014.

SANCHEZ, A. L.; FAIRFIELD, T. Using electronic technology for Taenia solium education: educating the educators. Acta Tropica, Amsterdam, v. 87, n. 1, p. 165170, 2003. 
SCANDRETT, B.; PARKER, S.; FORBES, L.; TESSELE, B.; BRUM, J. S.; BARROS, C. S. L. GAJADHAR, A.; DEKUMYOY, P.; JITRA, W.; Lesões parasitárias encontradas em bovinos abatidos HAINES, D. Distribution of Taenia saginata cysticerci para consumo humano. Revista Pesquisa Veterinária in tissues of experimentally infected cattle. Veterinary Parasitology, Amsterdam, v. 164, n. 2-4, p. 223-231, 2009. Brasileira, Seropédica, v. 33, n. 7, p. 873-889, 2013.

VARELA-RUIZ, M.; DÍAZ-BRAVO, L.; GARCÍADURÁN, R. Descripción y usos del método Delphi en investigaciones del área de la salud. Investigación en Educación Médica, México, v. 1, n. 2, p. 90-95, 2012. 